\title{
Halley Pacheco de Oliveira
}

\section{Halley Pacheco de Oliveira}

Pedro C. Junqueira

No albor da manhã do dia 22 de maio de 2000, começava a me preparar para iniciar a instalação do Congresso Comemorativo dos 50 anos da fundação da SBHH. Iríamos homenagear fundadores que ajudaram a engrandecê-la e destes, em especial, o meu querido companheiro - Professor Dr. Halley Pacheco de Oliveira - por ter realizado significativos congressos:

- O dos 10 anos de fundação da SBHH, no Rio de Janeiro;

- O da tentativa de realizar a união da SBHH e do CBH, em 1979, no Rio de Janeiro, no Hotel Othon.

Mas não há festejo completo. Às nove horas soube que Halley havia nos deixados órfãos neste mundo.

O que fazer? Prantear e despedir-me do companheiro de 51 anos de nossas vidas, ou cumprir, sem viço, as árduas funções de presidente deste Congresso, planejado durante um ano e meio de luta e trabalho?

Mas o homem, durante sua tênue existência, não é dono de si, mas servidor de funções e obrigações. Como tal, procurei homenageá-lo, na grande festa, no Teatro Municipal.

Terminado o Congresso, passada uma semana de descanso, comecei a relembrar os momentos agradáveis de nossas vidas: O Curso de Hematologia de Manguinhos, em 1949, nos aproximou, pois Walter O. Cruz, antitradicional, nos classificou como "aproveitamento excepcional". Na audácia de meus 33 anos e voltado para a hemoterapia, convidei este menino para trabalhar no meu Serviço, na Rua do México 31, para ganhar a vida e crescer na Hematologia, sua paixão, e junto lutamos pelas duas especialidades. Apresentei Halley aos membros do Serviço: Raul Ribeiro Alves (Nabisco), Paulo Jorge Whisart, Gladstone Deane, Deusdedit da Silva Braga (Jucá) e Ubiratan O. Peres (Bira) e também aos meus amigos, médicos importantes do Rio: Prof. Velho da Silva, C.Fraga Filho, Lopes Pontes. Ensinei-lhe hemo- terapia e assumiu as transfusões de sangue do Hospital dos Estrangeiros, dirigido pela comunidade inglesa. Enquanto a Clínica Hematológica não chegava, ganhava uns trocados com as transfusões. Bons anos de juventude quando, em 1951, fui para a Inglaterra, Halley ao escrever-me, em nome de todos, e deu-me o título de Lorde Macarra. Entretanto, o destino atingiu-me violentamente e nos separamos, conservando a amizade até o seu final.

Sempre contribuí para o seu desenvolvimento: aconselhei-o a ir para o Hospital dos Servidores do Estado, pois seria o hematologista de lá. Aloysio Salles da Fonseca, hematologista pós-graduado em Ann Arbor, nos EUA, não se fixaria na Hematologia, pois, o conhecia bem, desde o tempo em que deixou o Pronto Socorro para ser oficial de gabinete de seu tio Apolônio Salles. Aloysio, pouco tempo depois de ser o hematologista do HSE, passou a ser diretor deste hospital e exercer outros cargos importantes.

Halley, então, tornou-se o hematologista do HSE, formando uma equipe de referência de casos de hemopatias. Lá permaneceu de 1955 a 1977, destacando-se com suas assistentes Dras. Maria Nazareth Petrucelli, Maria Tereza Attem e Lieselotte Laun. Este serviço foi ativo, formando, até 1979, 11 especialistas em hematologia, que exercem até hoje suas atividades em vários centros universitários e hospitais do País. Em 1977, coroando o seu trabalho, publicou um tratado sobre Hematologia Clínica, livro que teve três edições.

Ao rejeitar, em 1979, seguir a tradição da SBHH de ser seu presidente, escreveu uma carta justificando os motivos de sua atitude:

" Minha vocação para o ensino, para o qual encontro, agora, oportunidade de realização, ao lado de Pedro Clovis Junqueira, chefe do Serviço de Hemoterapia daquele Hospital"

Presidente honorário da Sociedade Brasileira de Hematologia e Hemoterapia

Membro da Academia Brasileira de Medicina

Correspondência: Pedro Junqueira

R. Prudente de Morais, 985 - apto 104 - Ipanema

22420-041 - Rio de Janeiro-RJ

Tel.: (21) 2522-9951 
Em 1980, ao entardecer de nossas vidas, voltamos novamente juntos a sonhar, a lutar pelas nossas especialidades. Destas algumas devem ser recordadas:

1. A proximidade das duas especialidades hematológicas: Halley nomeado chefe do Serviço de Hematologia do Hospital Universitário da UFRJ, hoje Clementino Fraga Filho, recebeu, no $7^{\circ}$ andar, uma sala administrativa, como os demais chefes de serviço. Junto ao Serviço de Hemoterapia existiam duas salas do Laboratório do Hospital destinadas a exames hematológicos. Procurei Fraga e disse-lhe que era um absurdo Halley permanecer no $7^{\circ}$ andar, pois deveria ter uma das salas do Laboratório e ficarmos juntos. Falei tantas vezes que ele resolveu seguir minha opinião e no dia do Anschluss (destruição de uma parede entre laboratório e hemoterapia) ficamos juntos novamente. Dei a primeira sala do Serviço de Hemoterapia para Halley, o que nos aproximou diariamente. Palatnik, que ocupava provisoriamente esta sala, foi transferido para a sala de pesquisa (de $50 \mathrm{~m}^{2}$ ).

2. Ensino da Hematologia e da Hemoterapia integrados, o grande sonho não realizado:

" A formação dos hematologistas e dos hemoterapeutas deve obedecer aos imperativos de suas especialidades e à realidade das diversas comunidades brasileiras. Portanto, ela deve ser feita em três ciclos:

$1^{\circ}$ ciclo: O objetivo é formar um especialista com visão global da hematologia, da hematologia clínica e da hemoterapia, capacitando-o a exercê-las em qualquer comunidade brasileira.

$2^{\circ}$ ciclo: $\mathrm{O}$ objetivo é formar um especialista diferenciado e com conhecimento mais profundo em Hematologia
Clínica ou Hemoterapia, capacitando-o a exercer uma destas atividades em uma comunidade de desenvolvimento médio ou grande.

$3^{\circ}$ ciclo: (Optativo): O objetivo é aprofundar o conhecimento em uma determinada área da Hematologia, de modo a torná-lo um profissional diferenciado (clínico ou pesquisador), capacitando-o a exercer sua atividade em um local desenvolvido

Na UFRJ, a integração anatômica e funcional entre os Serviços de Hematologia Clínica e da Hemoterapia com o do Laboratório do Serviço de Patologia Clínica, do HU é ímpar, no Brasil, e permite a realização do Ciclo de Mestrado, com característica acima descrita, por PCJ e HPO.

Este ano faço 90 anos e estou próximo da minha saída deste mundo. Morreria tranqüilo se realizasse este sonho, que foi tão forte que guardo papéis escritos por mim e por Halley, os quais hoje estou levando para os jovens de ontem e maduros hematologistas do Serviço de Hematologia do Hospital Universitário Clementino Fraga Filho, de hoje. Há várias versões de um só tema sonho - o ensino da Hematologia e da Hemoterapia no Fundão e na PUC, que apresentamos em anexo para não ser repetitivo como o velho é.

O texto final sofreu revisão do professor Nelson Spector e foi publicado após a concordância do Editor.

Recebido: 06/03/2006

Aceito após modificações: 22/03/2006 